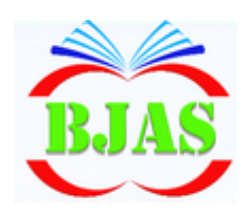

ISSN $1814-5868$
Available online at http://bjas.bajas.edu.iq

https://doi.org/10.37077/25200860.2020.33.1.14

College of Agriculture, University of Basrah

Basrah J. Agric. Sci. 33(1): 189-199, 2020

\section{Basrah Journal of Agricultural Sciences}

E-ISSN: 2520-0860

\title{
Growth Performance and Feed Efficiency Assessment of Two Groups of Common Carp (Cyprinus carpio L.) Cultivated in Iraq
}

\author{
Kadhim O.M. Al-Humairi' ${ }^{1}$ Riyadh A. Al-Tameemi ${ }^{2 *}$ \& Sajed S. Al-Noor ${ }^{2}$ \\ ${ }^{1}$ Al-Musaib Technical College, Al-Furat Al-Awsat Technical University, Babylon, Iraq. \\ ${ }^{2}$ Department of Fisheries and Marine Resources, College of Agriculture, University of Basrah, \\ Basrah, Iraq. \\ *Corresponding author: dr.raltameme@gmail.com
}

Received 15 March 2020; Accepted 4 June 2020; Available online 27 June 2020

\begin{abstract}
Laboratory experiments were conducted to compare the growth performance and feed efficiency of two groups, old (H1) and new (H2) of common carp Cyprinus carpio L. $(97.37 \pm 0.33 \mathrm{~g})$. Fishes of the H1 introduced to Iraq in 1982 and then their reproduction and farming began on a large scale, while fishes of the $\mathrm{H} 2$ was introduced to Iraq in 2009 by Inmaa Agricultural Enterprises Organization. H2 group indicated significantly $(\mathrm{p} \leq 0.05)$ better performance in several studied parameters which included specific growth rate (SGR), feed conversion ratio (FCR), protein efficiency ratio (PER), protein productive value (PPV), total apparent digestibility and apparent digestibility of protein and carbohydrates. This group also recorded significant $(\mathrm{p} \leq 0.05)$ lower feed satiation level and fat deposited in the body compared to the old group (H1). Results of the current experiment concluded that there is a clear higher efficiency of the group $\mathrm{H} 2$ in most studied growth and feed efficiency parameters, which indicates the possibility of obtaining higher productivity and better economic profits when used in farming activities.
\end{abstract}

Key words: Common carp, Growth, Feed efficiency.

\section{Introduction}

Most countries of the world seek to achieve stability in food security by design future plans to support and develop food-producing sectors that directly affect the social and economic reality of these countries (FAO, 2014). Fishes meat is rich in omega-3 fatty acids, and considered as a valuable source for several other essential nutrients. Fishes constitute about $16 \%$ of total produced animal protein globally (Pradeepkiran, 2019).
Rapid population growth as well as increased wealth and urbanization in developing countries have led to major changes in the supply and demand off animal protein, while fishes consumption in developing countries is expected to increase by $57 \%$, from 62.7 million tons in 1997 to 98.6 million tons in 2020 (Delgado et al., 2003).

Common carp Cyprinus carpio was introduced for the first time in 1955 to Iraq (AlHamed, 1967). A new breeders was introduced in 1982 from Hungary and used by the 


\section{Al-Humairi et al. / Basrah J. Agric. Sci., 33(1): 189-199, 2020}

company which constructed Al-Wahda Fish Hatchery (Al-Abbadi, 2015), since then they were used for reproduction and farming. absent of new genetically improved brooders led to deterioration in some productive characteristics of these fishes.

Represented by low growth rates, low feed conversion rate, elongation of the body and less resistance to diseases, these reasons led to the need to introduce new genetically improved brooders of common carp.

In 2009, Inmaa Agricultural Enterprises Organization imported a new production group of common carp from Hungary (Azawy \& Issa, 2019). Some local studies have been conducted on these old and new groups of common carp and their hybrids.

Al-Gypori \& Saleh (2012) investigated some reproductive characteristics of these two groups, as well as growth and feed conversion ratio of the first generation resulting from cross-breeding between them. Azawy \& Issa (2019) compared some somatic and reproductive characters between them.

The current study aims to compare some productive characteristics between these two production groups of common carp represented by the old group (H1) used since 1982 and the new group (H2) entered in the year 2009 which currently cultured in Iraq by studying growth and feed efficiency parameters in laboratory experiments for the purpose of answering fishes farmers question about the best productive group for use in their culture activities.

\section{Materials \& Methods}

All experiments were conducted in the laboratory of Fishes Nutrition, Department of Animal Production Techniques, Al-Musaib
Technical College, Al-Furat Al-Awsat Technical University. A recirculation closed system consisting of eight glass aquariums (150 litres), with dimensions of $100 \times 40 \times 50$ $\mathrm{cm}$ was used. The system was equipped with 1500 litres stock water tank, which used to compensation the missing water. The biological filter tank was equipped with heating devices to control water temperature as the experiment being conducted during the winter season. Experimental fishes common carp C. carpio for both groups was obtained from the ponds of Private Babylon Hatchery, Babylon province, Iraq. There were a distinction between the two groups, represented by the clear presence of a shiny line of scales that exists on both sides of the dorsal fin of the new group (Al-Abbadi, 2015; Azawy \& Issa, 2019).

\section{Growth and feed efficiency}

The growth experiment continued for 58 days from $20 / 12 / 2017$ to $15 / 2 / 2018$, after a 20 day acclimatization period. A total of 32 fishes $(97.37 \pm 0.33 \mathrm{~g})$ were used during the experiments, randomly divided by four fishes per aquarium and four aquariums per treatment. During the trial period, fishes were fed on an extruded commercial diet (Table 1) produced by Iraq Khairat factory, Baghdad, Iraq. Fishes were fed once per day in the morning up to satiation.

The proximate composition of the diet (Table 1), whole fishes and faeces were estimated by using standard methods of Olvera-Novoa et al. (1994). Carbohydrate (NFE+fibre) in the diet was estimated by difference.

Selected water quality parameters in aquariums were monitored weekly during the 


\section{Al-Humairi et al. / Basrah J. Agric. Sci., 33(1): 189-199, 2020}

experiments period represented by salinity PSU and $\mathrm{pH}$ (twice weekly). temperature ${ }^{\circ} \mathrm{C}$ (daily), dissolved oxygen $\mathrm{mg}^{-1}$,

Table (1): Proximate composition (\%) of the diet used during the experiments

\begin{tabular}{|l|l|}
\hline \multicolumn{1}{|c|}{ Proximate composition } & \multicolumn{1}{c|}{ Ratio (\%) } \\
\hline Moisture & $11.59 \pm 0.89$ \\
\hline Crude protein & $33.96 \pm 1.52$ \\
\hline Ether extract & $5.23 \pm 0.63$ \\
\hline Carbohydrate (NFE+fibre) & $43.40 \pm 3.10$ \\
\hline Ash & $5.82 \pm 0.17$ \\
\hline
\end{tabular}

At the end of the growth trial, fishes were weighed, and weight gain (WG), specific growth rate (SGR), feed conversion ratio (FCR), protein efficiency ratio (PER) and protein productive value (PPV) were calculated according to the following equations.

Weight gain $W G(g)=$

$$
\text { final weight }(g) \text { - initial weight }(g)
$$

Specific growth rate $S G R\left(\% g^{- \text {day }}\right)=$ $\frac{\text { ln final weight }(g)-\ln \text { initial weight }(g)}{\text { rearing period (days) }} \times 100$

Feed conversion ratio $F C R=$

$\frac{\text { dry feed intake }(g)}{\text { weight gain }(g)}$

Protein efficiency ratio $P E R=$ weight gain $(g)$

$\overline{\text { protein intake }(g)}$

Productive protein value PPV (\%) = $\frac{\text { protein gain }(g)}{\text { protein intake }(g)} \times 100$

\section{Digestibility}

At the end of the growth trial, digestibility trial was conducted according to the indirect method (Talbot, 1985). For the measurements of total and nutrients digestibility, one percent of chromic oxide $\left(\mathrm{Cr}_{2} \mathrm{O}_{3}\right)$ was served as the inert indicator in the diet. Fishes were fed to satiation once a day during the trail, voided faeces were collected by siphoning, about one hour after feeding. Chromium oxide concentration in faeces was estimated based on Olvera-Novoa et al. (1994). The total and nutrients apparent digestibility coefficients (TADC and NADC) were calculated as followed:

$$
\begin{aligned}
& T A D C=100-\left[100 \times \frac{\% \text { indicator in food }}{\% \text { indicator in faeces }}\right] \\
& N A D C=100-\left[100 \times \frac{\% \text { indicator in food }}{\% \text { indicator in faeces }} \times\right. \\
& \left.\frac{\% \text { nutrient in faeces }}{\% \text { nutrient in food }}\right]
\end{aligned}
$$

\section{Satiation level (SL)}

The trial of satiation lasted for 10 day, after digestibility trial, during that both groups of fishes were fed to excessed amount of feed as a one meal daily, for an hour (0800 to 0900 AM), uneaten feed was collected by siphoning, dried by air and weighed. Satiation level was estimated as a percentage of body weight according to the following equation:

Satiation level $\%=\frac{\text { feed consumed }(g)}{\text { body weight }(g)} \times 100$ Statistical analysis

Mean and standard deviation $($ Mean + SD) for all parameters were calculated. One-way analysis of variance (ANOVA) was used to 


\section{Al-Humairi et al. / Basrah J. Agric. Sci., 33(1): 189-199, 2020}

statistically analyse the obtained data of fishes growth, digestibility coefficients, feed efficiency and carcass composition at a significance level of 0.05 . Statistical analyses were performed with the IBM SPSS Statistics 22 software package.

\section{Results}

Parameters of aquariums water quality are shown in table (2). They were relatively stable, with small fluctuations during the study period. No fish mortality was observed during the experimental period.

Table (2): Water quality parameters in the experimental aquariums during experiments.

\begin{tabular}{|l|l|}
\hline \multicolumn{1}{|c|}{ Water quality parameters } & \multicolumn{1}{c|}{ Value } \\
\hline Temperature $\left({ }^{\circ} \mathrm{C}\right)$ & $24.65 \pm 1.17$ \\
\hline Dissolved oxygen $\left(\mathrm{mg} . \mathrm{l}^{-1}\right)$ & $6.36 \pm 1.39$ \\
\hline Salinity (PSU) & $0.58 \pm 0.03$ \\
\hline $\mathrm{pH}$ & $7.25 \pm 0.13$ \\
\hline
\end{tabular}

Fishes initial weight of both treatments was almost similar and had no significant differences $(\mathrm{p}>0.05)$. According to growth parameters at the end of trial, the new group of common carp (H2) was superior as compared with the old one (H1). As a result of the current study, final weight, weight gain and SGR indicated that the new group grew at a significantly greater rate $(\mathrm{p} \leq 0.05)$ than did the old group (Table 3).

Table (3): Growth performance and feed efficiency for common carp groups during the growth experiment.

\begin{tabular}{|l|l|l|}
\hline \multirow{2}{*}{ Parameters } & Treatments & \multicolumn{1}{c|}{$\mathrm{H} 2$} \\
\cline { 2 - 3 } & \multicolumn{1}{|c|}{$\mathrm{H} 1$} & $390.10 \pm 1.09^{\mathrm{a}}$ \\
\hline Initial weight $(\mathrm{g})$ & $388.85 \pm 1.40^{\mathrm{a}}$ & $569.98 \pm 14.78^{\mathrm{a}}$ \\
\hline Final weight $(\mathrm{g})$ & $528.15 \pm 21.56^{\mathrm{b}}$ & $179.88 \pm 15.44^{\mathrm{a}}$ \\
\hline Weight gain WG $(\mathrm{g})$ & $139.30 \pm 21.37^{\mathrm{b}}$ & $0.65 \pm 0.05^{\mathrm{a}}$ \\
\hline Specific growth rate SGR $\left(\% \mathrm{~g}^{\text {-day }}\right)$ & $0.53 \pm 0.07^{\mathrm{b}}$ & $1.81 \pm 0.15^{\mathrm{a}}$ \\
\hline Feed conversion rate FCR & $2.36 \pm 0.26^{\mathrm{b}}$ & $1.64 \pm 0.13^{\mathrm{a}}$ \\
\hline Protein efficiency ratio PER & $1.26 \pm 0.13^{\mathrm{b}}$ & $28.50 \pm 2.30^{\mathrm{a}}$ \\
\hline Protein produced value PPV $(\%)$ & $21.26 \pm 2.21^{\mathrm{b}}$ & \\
\hline
\end{tabular}

Means in the same raw with different superscript letters are significantly different $(\mathrm{P} \leq 0.05)$

Feed and protein efficiency parameters (FCR, PER and PPV) were illustrated in table (3). The data for these parameters were in the same trend found in growth results. The differences in these parameters between both $\mathrm{H} 1$ and $\mathrm{H} 2$ groups were significant $(\mathrm{p} \leq 0.05)$. $\mathrm{H} 2$ fishes group revealed better results. The growth and feed efficiency data are supported by data on the digestibility of the diet. In that sense, total, protein and carbohydrate digestibility coefficients (Table 4) were significantly $(\mathrm{p} \leq 0.05)$ higher in $\mathrm{H} 2$ fishes followed by $\mathrm{H} 1$ fishes. Nevertheless, lipid and ash digestibility coefficients were almost close for both groups and had no significant differences $(p>0.05)$ between them. 
Al-Humairi et al. / Basrah J. Agric. Sci., 33(1): 189-199, 2020

Table (4): Total and nutrients apparent digestibility coefficients (\%) for common carp groups during the digestibility experiment

\begin{tabular}{|l|c|c|}
\hline \multirow{2}{*}{ Digestibility coefficients } & Treatments & $\mathrm{H} 2$ \\
\cline { 2 - 3 } & $\mathrm{H} 1$ & $69.86 \pm 1.03^{\mathrm{a}}$ \\
\hline Total digestibility coefficient & $64.89 \pm 1.22^{\mathrm{b}}$ & $85.00 \pm 2.70^{\mathrm{a}}$ \\
\hline Protein digestibility coefficient & $77.89 \pm 2.62^{\mathrm{b}}$ & $94.16 \pm 2.03^{\mathrm{a}}$ \\
\hline Lipid digestibility coefficient & $93.13 \pm 1.83^{\mathrm{a}}$ & $68.86 \pm 2.25^{\mathrm{a}}$ \\
\hline Carbohydrate digestibility coefficient & $63.28 \pm 2.33^{\mathrm{b}}$ & $10.78 \pm 4.19^{\mathrm{a}}$ \\
\hline Ash digestibility coefficient & $9.45 \pm 5.31^{\mathrm{a}}$ & \\
\hline
\end{tabular}

Means in the same raw with different superscript letters are significantly different $(\mathrm{P} \leq 0.05)$

Satiation levels of experimental fishes are $1.64 \pm 0.30$ and $1.49 \pm 0.35 \%$ of body weight for $\mathrm{H} 1$ and $\mathrm{H} 2$ groups respectively. Results indicated that $\mathrm{H} 2$ fishes significantly $(\mathrm{p} \leq 0.05)$ consumed a smaller amount of feed compared to $\mathrm{H} 1$ group.

Proximate analysis of $\mathrm{H} 2$ fishes exhibited a decrease in the lipid content compared to $\mathrm{H} 1$ fishes, as it significantly $(\mathrm{p} \leq 0.05)$ decreased from 8.15 to $5.95 \%$. However, the results of moisture, protein and ash content of fishes of both groups showed no any considerable variations, with no significant differences ( $p>0.05)$ between them, as can be noticed in table (5).

Table (5): Proximate body composition (\%) of common carp groups at the end of experiments.

\begin{tabular}{|l|c|c|}
\hline \multirow{2}{*}{ Proximate body composition } & \multicolumn{2}{|c|}{ Treatments } \\
\cline { 2 - 3 } & $\mathrm{H} 1$ & $\mathrm{H} 2$ \\
\hline Moisture & $71.93 \pm 1.09^{\mathrm{a}}$ & $73.61 \pm 1.13^{\mathrm{a}}$ \\
\hline Protein & $16.85 \pm 0.42^{\mathrm{a}}$ & $17.43 \pm 0.66^{\mathrm{a}}$ \\
\hline Lipid & $8.15 \pm 0.95^{\mathrm{b}}$ & $5.95 \pm 0.90^{\mathrm{a}}$ \\
\hline Ash & $3.07 \pm 0.29^{\mathrm{a}}$ & $3.01 \pm 0.24^{\mathrm{a}}$ \\
\hline
\end{tabular}

Means in the same raw with different superscript letters are significantly different $(\mathrm{P} \leq 0.05)$

\section{Discussion}

As the genetic properties have important impact on growth of fishes in addition to the environmental conditions, the environmental conditions in laboratory trials must be controlled, and therefore the genetic impact could be measured (Magnussen, 2007). Temperature and dissolved oxygen were kept almost equally during the study period among aquariums. Therefore, the results indicated that they were relatively stable during all experiments. Simultaneously, salinity and $\mathrm{pH}$ had minor variations. All measured parameters were within appropriate limits for survival and growth of common carp (Goran et al., 2016).

Results of the current study obviously demonstrate that the SGR values of $\mathrm{H} 2$ group had superior values comparing to $\mathrm{H} 1$ group. Current results are in agreement with Al-Gypori \& Saleh (2012) when they compared the growth criteria of the same two groups.

Furthermore, recorded value of SGR for $\mathrm{H} 2$ group $\left(0.65 \% \mathrm{~g}^{\text {-day }}\right)$ of the present study is higher than the SGR of several local previous studies on $\mathrm{H} 1$ group such as Al-Hamadany (2008), Al-Dubakel \& Al-Sanabani (2010), 


\section{Al-Humairi et al. / Basrah J. Agric. Sci., 33(1): 189-199, 2020}

Abulhini et al. (2013) and Al-Refaiee et al. (2016) which reached $0.57,0.48,0.25$ and 0.63 $\% \mathrm{~g}^{\text {-day }}$, respectively. Selective breeding was a highly effective and sustainable means of improving productivity. Therefore, the higher growth values observed in the current study may be explained by the better genetic properties of the $\mathrm{H} 2$ group.

Several successful genetic improvement programs of cultured aquatic animal species have been developed over the last four decades achieving genetic gains between 10 and $20 \%$ per generation for economically important traits (Ponzoni et al., 2013). Additionally, Hussain \& Mazid (2005) declared that carps have revealed growth reduction possibly due to genetic deterioration which causes adverse impacts on aquaculture production. Furthermore, other studies pointed out that the inherent capacity of selective breeding could be a reason for faster growth as mentioned for Rohu (Labeo rohita) by Reddy et al. (2002) and Nile tilapia (Oreochromis niloticus) by Ibrahim et al. (2013). Eknath et al. (1993) reported that, next to one or two generations, African strains of Nile tilapia, performed better growth than domesticated strains used by fishes farmers in Philippine. Espinosa-Chaurand et al. (2019) also pointed that the difference in the growth between two strains of tilapia was very likely due to the genetic selection.

The efficiency of diet utilization varied with the studied groups of fishes, and hence feed efficiency values (FCR, PER and PPV) obtained in the present trial revealed a clear superiority for the $\mathrm{H} 2$ group. $\mathrm{H} 2$ group recorded considerably better FCR value (1.81) compared with H1 group, which recorded 2.36. Similar trends have been noticed for the protein efficiency criteria (PER and PPV). These results could be indicated that the $\mathrm{H} 2$ group was more efficient in feed efficiency and protein utilization than the $\mathrm{H} 1$ group. These results are consistent with the finding of Abdel-Tawwab (2004) on Nile tilapia.

The apparent digestibility coefficient is an important indicator that shows the percentage of digested and absorbed food by fishes. The higher apparent digestion coefficient values lead to a reduction in the loss of the amount of feed consumed with a decrease in the amount of waste excreted and thus a decrease in the percentage of water contamination (Hassan et al., 2017).

Mohammad \& Al-Safo (2013) indicated that improving the apparent digestibility coefficients leads to an improvement in the growth parameters. The current study showed that the faster growing $\mathrm{H} 2$ group recorded significantly higher values in relation to the total, protein and carbohydrates apparent digestibility coefficients compared to H1 group, while there were no significant differences in the values of the apparent digestibility coefficients of the fat and ash for both groups of fishes. Rasmussen \& Jokumsen (2009) stated that selective breeding could be a reason for improving the protein digestibility when comparing different rainbow trout families. Moreover, Li et al. (2019) stated that genetic selection might help to breed new gibel carp Carassius gibelio strains with improved carbohydrate and lipid utilization abilities.

Hepher (1988) stated that fishes differ in satiation levels, and that the amount of food consumed in one meal represents the satiation level. As noted by Glencross et al. (2007), to the necessity of feeding beyond the apparent 


\section{Al-Humairi et al. / Basrah J. Agric. Sci., 33(1): 189-199, 2020}

satiation, because fishes in order to express their response to food, must be given the chance to reject it. The current results showed that the amount of food needed to reach the satiation level was significantly $(\mathrm{p} \leq 0.05)$ reduced in the $\mathrm{H} 2$ group (1.49 \% of body weight) compared to the $\mathrm{H} 1$ group (1.64\% of body weight). These results indicate that fishes of $\mathrm{H} 2$ group reached the satiation level with a smaller amount of food, which indicates a higher efficiency to benefit from food.

Al-Dubakel \& Al-Sanabani (2010) stated that the amount of feed intake with a little satiation level is subsequently reflected on the feed conversion rates, and this is what was observed through the results of the current experiment. Eriegha \& Ekokotu (2017) likewise indicated that the satiation level in fishes is affected by the digestibility of feed materials, and this is consistent with the results of digestibility in the current study. It is noticed, from the results of the current study, that the moisture content in bodies of fishes of $\mathrm{H} 1$ and $\mathrm{H} 2$ groups showed a decrease associated with an increase in the body fat content. These results are similar to many previous studies (Salam et al., 2000; Cheng \& Hardy, 2004; Dempson et al., 2004) showed that moisture content is inversely related to fat content of fish body. H1 fishes showed an increase in the body fat content compared to $\mathrm{H} 2$ fishes, which indicates a higher ability to precipitate fat into the body. Amancio et al. (2019) declared that consuming higher amount of feed, caused higher deposition of fat in fish body, due to higher intake of digestible energy. The results of the current study showed that fishes of both groups did not significantly differ in the body content of protein. Indicated by Yigit et al. (2006) that the difference in protein content in fish body depends on genetic factors and as the two groups of the present study belong the same species (C. carpio), therefore, they did not differ in their protein content.

\section{Conclusions}

The results of the current experiments concluded that there is a clear higher efficiency of fishes of the new group (H2) which was introduced to Iraq in 2009 , as they have a shiny line of scales that exists on both sides of the dorsal fin in most growth and feed efficiency parameters. This indicates the possibility of obtaining higher productivity and better economic profits when used in fishes farming (aquaculture) activities.

\section{Acknowledgements}

We are immensely grateful to our colleagues from the Department of Fisheries and Marine Resources, College of Agriculture, University of Basrah. Moreover, we would like to demonstrate our gratitude to the Engineer Mr. Sabah Ajimi, Director of the Babylon Reserve.

\section{Conflicts of interest}

The authors-declare-that they-have-no-conflict of interests.

\section{Ethical approval}

All applicable institutional, national and international guidelines for the care and use of animals were followed.

\section{References}

Abdel-Tawwab, M. (2004). Comparative Growth Performance and Feed Utilization of Four Local Strains of Nile Tilapia (Oreochromis niloticus L.), Collected from Different Locations in Egypt. 510-517. In: Bolivar, R.; Mair, G. \& Fitzsimmons, K. 


\section{Al-Humairi et al. / Basrah J. Agric. Sci., 33(1): 189-199, 2020}

(Eds.). The $6^{\text {th }}$ Int. Symp. on Tilapia in Aquaculture, Manila, Philippines: 808pp.

https://cals.arizona.edu/azaqua/ista/ista6/ista6w eb/pdf/510.pdf

Abulhini, A.J.; Abbas, L.M. \& Mohammed, S.D. (2013). The effects of starvation on growth for common carp (Cyprinus carpio L.). Basrah J. Agric. Sci., 26(2): 225-231. (In Arabic).

https://www.iasj.net/iasj?func=article $\&$ aId $=112$ 069

Al-Abbadi, K.I. (2015). Artificial Propagation of Fish and Hatcheries Management. Min. High. Educ., Found. Tech. Educ.: 273pp. (In Arabic).

Al-Dubakel, A.Y. \& Al-Sanabani, M.A. (2010). Using vitamin $\mathrm{C}$ and sodium bentonite as food additives in the diets of common carp Cyprinus carpio L. Iraqi J. Aquac., 7(1): 4362. (In Arabic).

https://www.iasj.net/iasj?func=article $\&$ aId $=483$ 27

Al-Gypori, M.O.A. \& Saleh, K.I. (2012). Evaluation of some productive and reproductive crossbreeding of two different lines of common carp (Cyprinus carpio L.). Al-Qadisiyah J. Vet. Med. Sci., 11(3): 2434. (junior author's name misspelled Salihe, Kh. in the publication). (In Arabic).

https://doi.org/10.29079/vol11iss3art218

Al-Hamadany, Q.H. (2008). Growth rates of young Buni Barbus sharpeyi (Gunther, 1874) and common carp Cyprinus carpio L. under laboratory conditions. Iraqi J. Aquac., 5(2): 65-72. (In Arabic). https://www.iasj.net/iasj?func=article \&aId $=478$ 07

Al-Hamed, M.I. (1967). Carp Culture in the Republic of Iraq. I/E-1. In Pillay, T.V.R. (Ed.). Proc. FAO World Symp. on Warmwater Pond Fish Culture, Rome, Italy, 18-25 May 1966, regional and country reports. Rome: $174 \mathrm{pp}$.

http://www.fao.org/3/61036T/61036T10.htm.

Al-Refaiee, I.H.A.; Mutter, H.M. \& Abdulrahman, N.M. (2016). The effect of replacing different levels of commercial dry yeast (Saccharomyces cerevisiae) place animal protein concentrate in fingerlings fish common carp (Cyprinus carpio. Linnaeus 1758) diets. Al-Anbar J. Vet. Sci., 9(1): 8596. (In Arabic).

https://www.iasj.net/iasj?func=article \&aId=113 222

Amancio, A.L.L.; Neto, M.R.S.; Filho, J.J.; da Fonseca, S.B. \& da Silva, J.H.V. (2019). Dietary protein requirements for tambaqui Colossoma macropomum (Cuvier, 1818) juvenile. Rev. Cienc. Agron., 50(2): 259266.

https://doi.org/10.5935/1806-6690.20190030

Azawy, M.S. \& Issa, A.A. (2019). Comparison of some somatic and reproductive characters for two brood stock of Cyprinus carpio L.. J. Univ. Babylon, Pure Appl. Sci., 27(1): 228237. (In Arabic).

https://www.journalofbabylon.com/index.php/J UBPAS/article/view/2116

Cheng, Z.J. \& Hardy, R.W. (2004). Nutritional value of diets containing distiller's dried grain with solubles for rainbow trout, 


\section{Al-Humairi et al. / Basrah J. Agric. Sci., 33(1): 189-199, 2020}

Oncorhynchus mykiss. J. App. Aquac., 15(3-

4): 101-113.

https://doi.org/10.1300/J028v15n03_08

Delgado, C.L.; Wada, N.; Rosegrant, M.W.; Meijer, S. \& Ahmed, M. (2003). Fish to 2020: Supply and Demand in Changing Global Markets. International Food Policy Research Institute (IFPRI), Washington and WorldFish Center, Penang, Malaysia. WorldFish Center Technical Report 62: 226pp.

http://www.ifpri.org/publication/fish-2020

Dempson, J.B.; Schwarz, C.J.; Shears, M. \& Furey, G. (2004). Comparative proximate body composition of Atlantic salmon with emphasis on parr from fluvial and lacustrine habitats. J. Fish Biol., 64(5): 1257-1271.

https://doi.org/10.1111/j.0022-

1112.2004.00389.x

Eknath, A.E.; Tayamenb, M.M.; Palada-de Vera, M.S.; Dantingb, J.C.; Reyesb, R.A.; Dionisiob, E.E.; Capili, J.B.; Bolivaf, H.L.; Abella, T.A.; Circa, A.V.; Bentsend, H.B.; Gjerded, B.; Gjedremd, T. \& Pullin, R.S.V. (1993). Genetic improvement of farmed tilapias: The growth performance of eight strains of Oreochromis niloticus tested in different farm environments. Aquaculture, 111(1-4): 171-188.

https://doi.org/10.1016/0044-8486(93)90035-W

Eriegha, O.J. \& Ekokotu, P.A. (2017). Factors affecting feed intake in cultured fish species: A review. Anim. Res. Int., 14(2): 26972709.

https://www.ajol.info/index.php/ari/article/view $/ 186884$
Espinosa-Chaurand, D.; Aparicio-Simon, B.; Cortes-Sanchez, A.J.; Garza-Torres, R.; Garcia-Morales, R. \& Maeda-Martinez, A.N. (2019). The productive assessment of two tilapia nilotica (Oreochromis niloticus) commercial strains in Sinaloa Mexico. Lat. Am. J. Aquat. Res., 47(3): 440-448.

https://doi.org/10.3856/vol47-issue3-fulltext-6

FAO (2014). The State of World Fisheries and Aquaculture 2014. Rome: 223pp.

http://www.fao.org/resources/infographics/info graphics-details/en/c/231544/

Glencross, B.D.; Booth, M. \& Allan, G.L. (2007). A feed is only as good as its ingredients - A review of ingredient evaluation strategies for aquaculture feeds. Aquac. Nutr., 13: 17-34.

https://doi.org/10.1111/j.13652095.2007.00450.x

Goran, S.M.A.; Omar, S.S. \& Anwer, A.Y. (2016). Water quality and physiological parameters of common carp fingerling fed on Jerusalem artichoke tubers. Polytechnic, 6(3): 502-516.

https://scholar.google.com/citations?user=NilR 3I4AAAAJ\&hl=en

Hassan, S.M.; Albassam, N.H. \& Alhabeeb, F.M. (2017). Determination total digestibility coefficient and evacuation rate in commercial diets added some dried leaves of plants used in feed common carps Cyprinus carpio. Tikrit Univ. J. Agric. Sci., 17(3): 164-171. (In Arabic).

https://www.iasj.net/iasj?func=article $\&$ aId $=129$ 329 


\section{Al-Humairi et al. / Basrah J. Agric. Sci., 33(1): 189-199, 2020}

Hepher, B. (1988). Nutrition of Pond Fishes. Cambridge Univ. Press: 388pp.

https://doi.org/10.1017/CBO9780511735455

Hussain, M.G. \& Mazid, M.A. (2005). Carp Genetic Resources of Bengladesh. 16-25. In: Penman, D.J.; Gupta, M.V. \& Dey, M.M. (Eds.). Carp Genetic Resources for Aquaculture in Asia. WorldFish Center Technical Report 65: 152pp.

https://www.worldfishcenter.org/content/carpgenetic-resources-aquaculture-asia

Ibrahim, N.A.; Abou Zaid, M.Y.; Khaw, H.L.; El-Naggar, G.O. \& Ponzoni, R.W. (2013). Relative performance of two Nile tilapia (Oreochromis niloticus Linnaeus) strains in Egypt: The Abbassa selection line and the Kafr El Sheikh commercial strain. Aquac. Res., 44: 508-517.

https://doi.org/10.1111/j.1365-

2109.2012.03240.x

Li, H.; Xu, W.; Jin, J.; Zhu, X.; Yang, Y.; Han, D.; Liu, H. \& Xie, S. (2019). Effects of dietary carbohydrate and lipid concentrations on growth performance, feed utilization, glucose, and lipid metabolism in two strains of gibel carp. Front. Vet. Sci., 6: $1-14$.

https://doi.org/10.3389/fvets.2019.00165

Magnussen, E. (2007). Interpopulation comparison of growth patterns of 14 fish species on Faroe Bank: Are all fishes on the bank fast-growing?. J. Fish Biol., 71(2): 453-475.

https://doi.org/10.1111/j.1095-

8649.2007.01502.x
Mohammad, M.A. \& Al-Safo, R.C.M. (2013). Effect of adding some probiotics supplementation to performance common carp Cyprinus carpio L. in glass aquaria. 1Growth and food utilization criteria. Mesopot. J. Agric., 41(2): 99-111. (In Arabic).

https://www.iasj.net/iasj?func=article $\&$ aId $=811$ 04

Olvera-Novoa, M.A.; Martinez-Palacios, C.A. \& Real De Leon, E. (1994). Nutrition of Fish and Crustaceans: A Laboratory Manual. FAO, Rome: 58pp.

http://www.fao.org/3/ab479e/AB479E00.htm

Ponzoni, R.W.; James, J.W.; Nguyen, N.H.; Mekkawy, W. \& Khaw, H.L. (2013). Strain Comparisons in Aquaculture Species: A Manual. WorldFish, Penang, Malaysia. Manual: 2013-12: 31pp.

https://www.worldfishcenter.org/content/straincomparisons-aquaculture-species-manual-0

Pradeepkiran, J.A. (2019). Aquaculture role in global food security with nutritional value: A review. Transl. Anim. Sci., 3(2): 903-910.

https://doi.org/10.1093/tas/txz012

Rasmussen, R.S. \& Jokumsen, A. (2009). Digestibility in selected rainbow trout families and relation to growth and feed utilisation. Aquac. Int., 17(2): 187-197.

https://doi.org/10.1007/s10499-008-9191-9

Reddy, P.V.G.K.; Gjerde, B.; Tripathi, S.D.; Jana, R.K.; Mahapatra, K.D.; Gupta, S.D.; Saha, J.N.; Sahoo, M.; Lenka, S.; Govindassamy, P.; Rye, M. \& Gjedrem, T. (2002). Growth and survival of six stocks of rohu (Labeo rohita, Hamilton) in mono and 


\section{Al-Humairi et al. / Basrah J. Agric. Sci., 33(1): 189-199, 2020}

polyculture production systems. Aquaculture, 203(3-4): 239-250.

https://doi.org/10.1016/S0044-8486(01)005403

Salam, A.; Ali, M. \& Masud, S. (2000). Effect of various food deprivation regimes on body composition dynamics of thaila, Catla catla. J. Res., Sci., 11(1): 26-32.

https://www.bzu.edu.pk/jrscience/vol11no1/5.p hp

Talbot, C. (1985). Laboratory Methods in Fish
In: Tytler, P. \& Calow, P. (Eds.). Fish Energetics: New Perspectives. Springer, Dordrecht: $349 \mathrm{pp}$. https://doi.org/10.1007/978-94-011-7918-8_5 Yigit, M.; Erdem, M.; Koshio, S.; Ergün, S.; Türker, A. \& Karaali, B. (2006). Substituting fish meal with poultry by-product meal in diets for Black Sea turbot Psetta maeotica. Aquac. Nutr., 12(5): 340-347.

https://doi.org/10.1111/j.13652095.2006.00409.x

Feeding and Nutritional Studies. 125-154.

تقييم اداء النمو وكفاءة التغذية لمجموعتين من اسماك الكارب الثائع (Cyprinus carpio L. المستزرع في العراق

$$
\begin{aligned}
& \text { كاظم عبيا مطر الحميري ورياض عدنان التميمي² وساجد سعد النور2 } \\
& \text { 1الكلية التقنية/ المسيب، جامعة الفرات الاوسط التقنية، بابل، العراق } \\
& \text { 2قسم الاسماك والثروة البحرية، كلية الزراعة، جامعة البصرة، البصرة، العراق }
\end{aligned}
$$

المستخلص: اجريت التجربة المختبرية لمقارنة اداء النمو وكفاءة التغذية لمجموعتين، القديمة (H1) والجديدة (H2) من اسماك

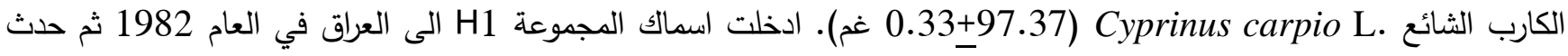
التوسع الكبير في تكثيرها واستزراعها، بينما ادخلت اسماك المجموعة H2 الى العراق في العام 2009 بواسطة منظمة أنما للمشاريع الزراعية. اظهرت اسماك المجموعة H2 اداء افضل بما يتعلق بالعديد من المقاييس المدروسة تمثلت بمعدل النمو النوعي (SGR) ومعدل التحويل الغذائي (FCR) ونسبة كفاءة البروتين (PER) وقيمة البروتين المنتج (PPV) وقابلية الهضم الظاهرية الكلية وقابلية الهضم الظاهري للبروتين والكاربوهيدرات. كما سجلت اسماك هذه المجموعة مستويات اقل معنويا (0.05>p) للإشباع وترسيب للدهون في الجسم مقارنة باسماك المجوعة القديمة (H1). استنتجت نتائج الدراسة الحالية ان اسماك المجموعة H2 تمتلك وبشكل واضح كفاءة اعلى فيما يتعلق بمعظم مقاييس النمو وكفاءة التغذية المدروسة، مما يؤدي الى احتمالية اكبر في الحصول على انتاجية اعلى لهى وارباح افضل عند استخدامها في انثطة الاستزراع السمكي. الكلمات المفتاحية: الكارب الثائع، النمو، كفاءة التغذية. 